\title{
Kuinka pelimanniutta tehdään pukeutumisella
}

Univormu - sitähän me emme itse valitse, se määrätään meille. Se edustaa yleispätevää varmuutta yksilöllisen epävakaisuuden vastapainona. Kun ennen niin varmat arvot joutuvat kyseenalaisiksi ja loittonevat kumaraisin päin, ihminen joka ei osaa elää ilman niitä (ilman uskollisuutta, perhettä, isänmaata, kuria, rakkautta) napittautuu univormussa yleispätevyyteen aina vihoviimeistä nappia myöten kuin viimeiseen ylimaallisuuden rihmaan, joka vielä voi suojella häntä kylmältä ja mitään kunnioittamattomalta tulevaisuudelta. (Milan Kundera: Romaanin taide.)

Bo Lönnqvistin mukaan tiettyjä rooleja ei voida esittää ilman niihin perinteellisesti kuuluvaa pukua. Asuessani Englannissa todellakin hämmästyin huomatessani, etteivät tapaamani terveyskeskuslääkärit käyttäneet vastaanotolla minkäänlaisia virka-asuja. Suomessa lääkärit, sairaanhoitajat ja vastaanottohenkilökunta erottautuvat toisistaan ja potilaista pukujensa, niiden värien ja mallien mukaan. Me tunnistamme lääkärin tai papin heidän pukunsa perusteella ja ällistymme, jos he toimivat virassaan käyttämättä "asiaan kuuluvaa pukua". (Lönnqvist 1979, 21.)

Edelliset esimerkit viittaavat siihen pukeutumisperinteen osa-alueeseen, josta ranskalainen semiootikko Roland Barthes on käyttänyt ilmaisua le costu$m e$. Se on olennaisesti yhteisöllinen, institutionaalinen realiteetti. Se ei riipu yksilöstä ja se on normatiivinen: kun yksilö on sonnustautunut pukuun, hänen on käyttäydyttävä kunnolla. Puku on myös tiedottava. Se rakentaa suhdetta puvun kantajan ja ryhmän välillä. (Barthes 1957; op. cit. Lönnqvist 1972, 19.) Toinen Barthesin luonnehtima pukeutumisluokka on l'habillement eli vaatteet. Se on yksilöllinen realiteetti, jossa yksilö toteuttaa costumea vaatteissaan.

Jotta puvun merkit ymmärrettäisiin oikein, ne pitää oppia aivan samoin kuin erilliset kielet, venäläinen etnografi Petr G. Bogatyrev väitti. Hän analysoi sitä, kuinka siirtyminen pukeutumisen funktiosta toiseen tapahtuu. (Bogatyrev 1971, op. cit. Lönnqvist 1972, 26.)

Tässä artikkelissa esittelen yhden pohjoishämäläisen musiikkikokoonpanon, Virtain pelimannien, esiintymispukujen merkkejä ja niistä tekemiäni tulkintoja. Kenttätyöni kuluessa olen dokumentoinut pelimannien keskusteluja puvuistaan: analysoin tässä näitä keskusteluja. Olen myös kerännyt valokuvia, 
kuvannut ja pannut merkille heidän asujaan eri tilanteissa. Valokuvat ovat tässä mukana lähinnä havainnollistamassa kertomaani.

Vaatteen funktiot liittyvät Bogatyrevin mukaan yhtäältä konkreettisesti ruumiin verhoamiseen, toisaalta symbolisiin sfääreihin. Jälkimmäiset funktiot ovat siis abstrakteja merkkejä. Juhlapukeutumisessa ovat etualalla (1) juhlatilaisuus, (2) esteettinen aspekti (3) rituaalinen aspekti. Niiden jälkeen tulevat (4) alueellinen kuuluvaisuus, (5) sääty ja (6) praktiset asiat. Kolme viimeksi mainittua asiaa ja esteettisyys taas ovat Bogatyrevin mielestä merkittäviä arkipukeutumisessa ${ }^{1}$.

Bogatyrev kiinnittää huomiota myös siihen, mitä tapahtuu näiden pukeutumisluokkien välissä: tuolloin tietyt funktiot vahvistuvat, toiset taas heikentyvät ja tapahtuu uudelleen ryhmitystä. Esimerkiksi säätyfunktio puvussa voi saada kansallisen funktion - näin lienee käynyt kansallispuvun tapauksessa. (Bogatyrev 1971, op. cit. Lönnqvist 1972, 26.) Pelimannien pukuja tarkasteltaessa näyttäisikin siltä, että ainakin alueelliset ja paikalliset aspektit - jos eivät nyt suoranaisesti kansalliset - korostuvat kansallispukujen käytössä. Tämän kirjoituksen lukijalle käy myös selväksi, ettei käytännön asioitakaan voida juhlapukeutumisessa tyyten unohtaa. Kansallispuvut ovat muusikon esiintymisasuina epäkäytännöllisiä, ja tämä vähentää niiden käyttöä.

Bogatyrev korostaa perusstrukturalistiseen tapaan, ettei vaatteen struktuuria määrää sen funktioiden summa vaan suhteet toisiinsa rakenteellisesti liittyneiden funktioiden välillä. (op. cit. Lönnqvist 1972, 26.) Nämä suhteet ovat erityisen kiinnostavia pukeutumisluokkien välissä: pelimannien toinen esiintymisasu suorine housuineen ja trikoosamettiliiveineen sijoittuu juuri tähän välitilaan.

Bogatyrev tarkastelee pukeutumista osana sosiaalista järjestelmää. Tämä tarkastelunäkökulma on laajempi kuin esimerkiksi pukeutumista "kuvina" tarkastelevan Minna Uotilan (1995), joka suo esteettisille seikoille selkeästi etusijan ja sulkeistaa länsimaiseen pukeutumiseen liittyvät käytännön, moraaliset ja taloudelliset aspektit tutkimuskohteensa ulkopuolelle (mt. 23).

Uotila tuo esiin, Veijo Hietalaa soveltaen, "suomalaisen pukeutumisen ikonimaiseman". Kuuluvatko suomalaisuuden ikonit pelimanniuteen? Suomalaisiksi tunnistettavia pukeutumiskuvaelementtejä, ikoneja, näemme esimerkiksi tukkilaiselokuvissa. Niissä tulee esille mytologinen hahmo, joka on yhä elossa suomalaisen perusjätkän tai -naisenkin käsitteessä. Myös kulkurit, rillumareihahmot, Armi-tyypit ja Niskavuoren Hetat ovat tulleet osaksi valikoimaa, josta ammennamme identiteettiimme sopivia pukeutumistyyppejä. (Uotila mt. 168.)

\footnotetext{
${ }^{1}$ Rituaaliset asut (esimerkiksi hääpuvut) ovat oma lukunsa. Rituaaleissa edellä luetelluista funktioista kolmas, rituaalinen, siirtyy tärkeimmäksi ja sitä seuraavat juhla- ja esteettiset funktiot. (Bogatyrev, op. cit. Lönnqvist 1972, 18-19.)
} 


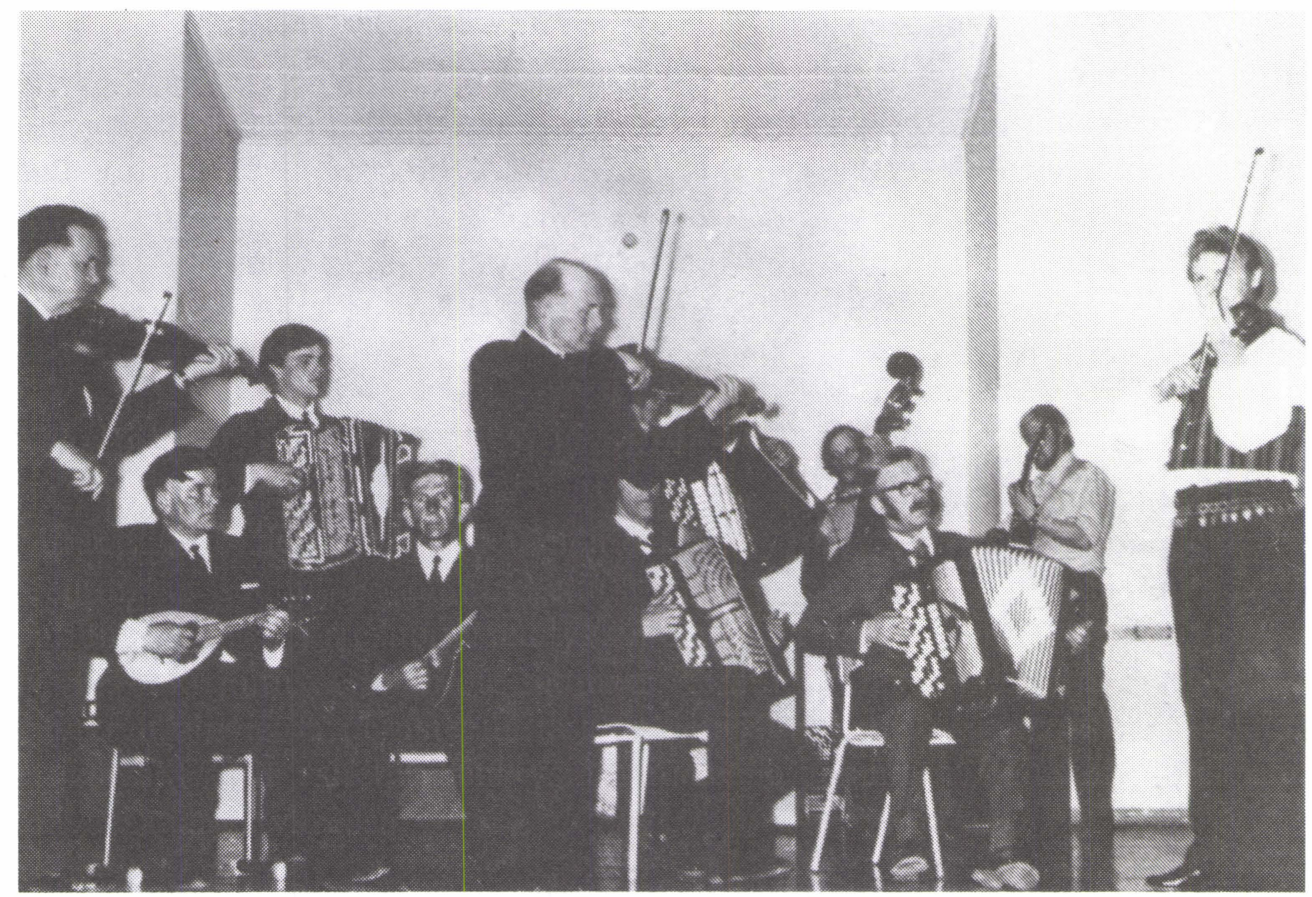

Kuva 1. Vaskiveden pelimannit esiintymässä Virtain kauppaoppilaitoksella vuonna 1973. Johtajalla ensi kertaa esiintymisessä yllään Virtain puku. Kuvan omistaa Yrjö Raja.

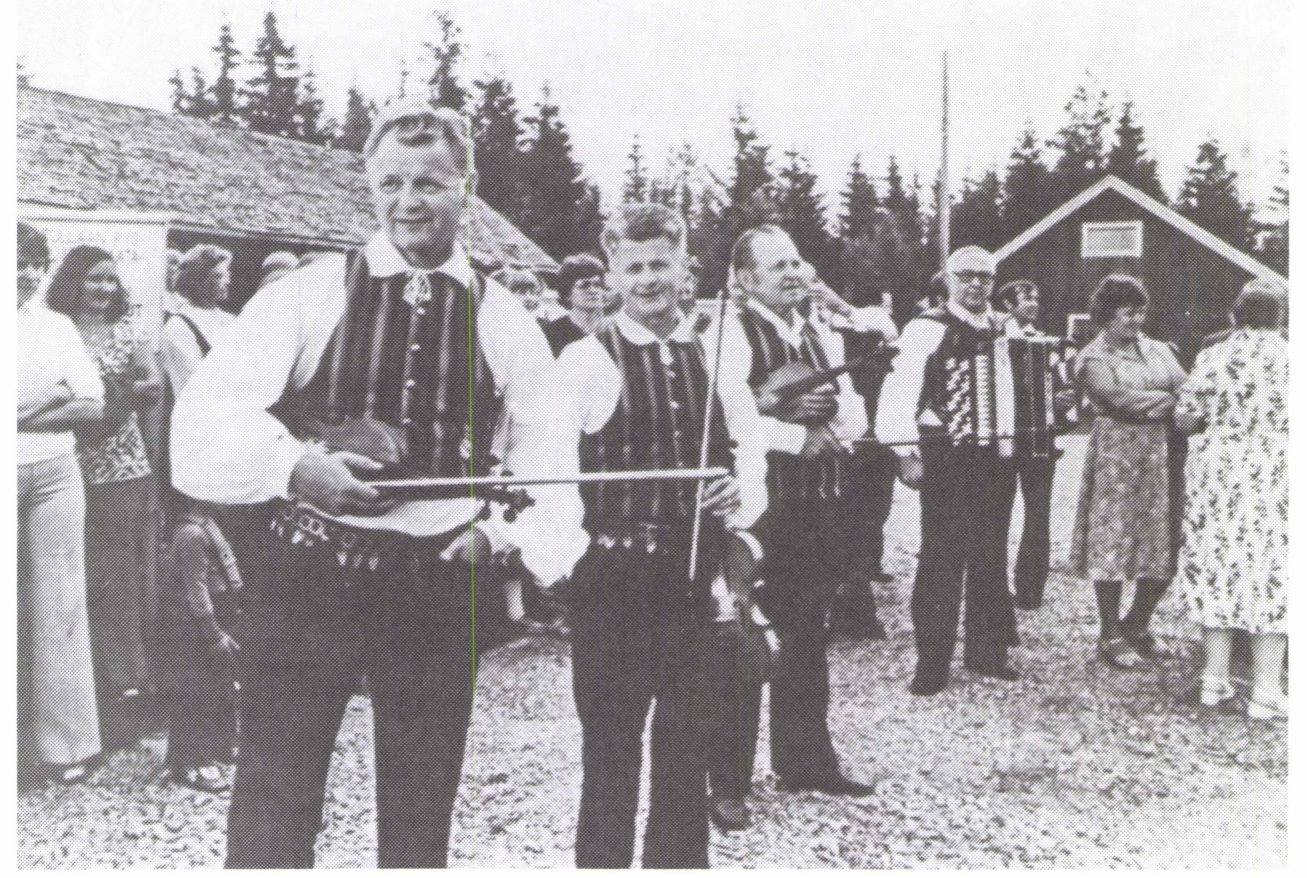

Kuva 3. Pelimanneja Virtain päivillä 1970-luvun loppupuolella. Kansallispuvut ovat käytössä. Kuvan omistaa Yrjö Raja. 


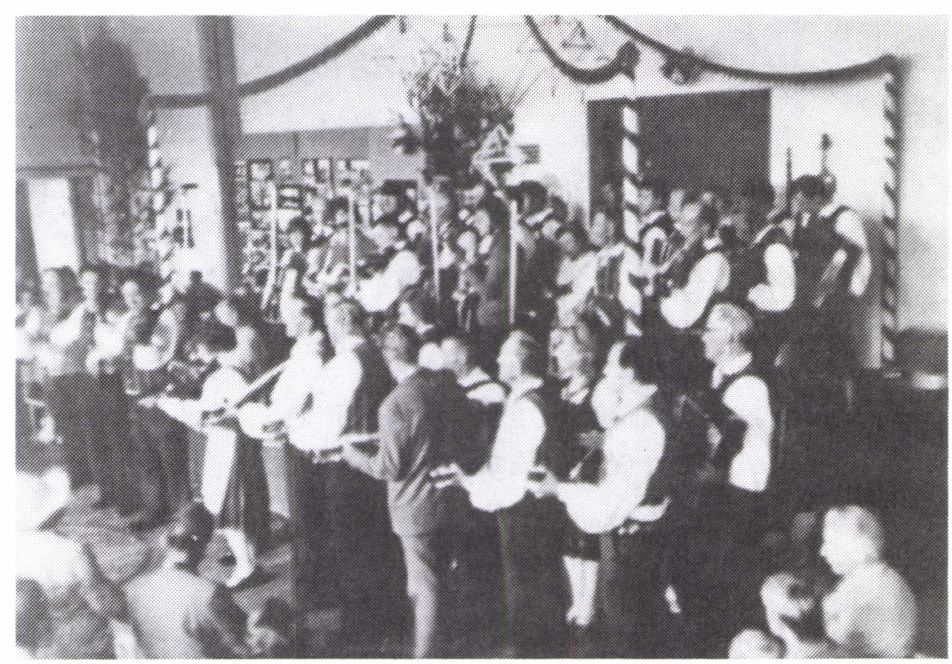

Kuva 2. Virtolaiset esittivät Kaustisen kansanmusiikkijuhlilla 1974 ohjelmakokonaisuuden "Virtolaisittain": suurimmalla osalla Virtain pelimanneista oli tuolloin jo kansallispuku. Kuvan omistaa Yrjö Raja.

Virtain pelimannit selvästikin rakentavat pelimanniuttaan ja ryhmänsä yhteisyyttä myös pukeutumisessa ja siihen liittyvässä vuorovaikutuksessa. Pukeutumisessa artikuloidaan (ks. esim. Järviluoma 1991) mm. edellä mainittuja elementtejä. Yhtäältä on nähtävissä voimakasta pyrkimystä kategorisointiin: puvut luonnehtivat pelimannien kategoriapiirteitä olennaisesti. Toisaalta ryhmän vuorovaikutuksessa on jatkuvasti läsnä partikularisointi, eriyttäminen. Pukujen kautta sekä ryhmä että erilliset pelimannit saattavat korostaa eroavaisuuksia. Tämä kategorisoinnin ja partikularisoinnin ristiriitainen voimakenttä leimaa ihmisten kaikkea jokapäiväistä kommunikaatiota (Billig 1987, 131; Järviluoma ja Roivainen [painossa]).

\section{Kansallispukujen hankinta}

Vuosisadan vaihteen pelimanni valmistautui soittotilaisuuksiin sonnustautumalla pyhävaatteisiin: hänellä oli "pesty naama hyvästi ja parta vinkkelissä" (Järviluoma 1986, 84). Erikseen olivat boheemityyppiset muusikot kuten haapavetinen Viina-Matti, jonka pukeutumista naureskeltiin: hän oli laittautunut naisten päällystakkiin ja baskeriin (mt. 59).

Virtolaiset nykypelimannitkaan eivät esiinny arkikamppeissaan. Tämä onkin ymmärrettävää, sillä ihmisellä on taipumus pitää yhteisöllisissä tapahtumissa parhaita vaatteitaan. Yhtyeen alkuaikoina virtolaiset eivät kuitenkaan kan- 
sallispukuja pitäneet. Piirin johtaja Yrjö Raja hankki ensimmäisenä virtolaisena Virtain miesten puvun ja käytti sitä esiintymisissä vuodesta 1973 lähtien. Ensimmäisissä pelimannipiireistä otetuissa valokuvissa pelimannit soittavat mustissa puvuissa, naiset jakkupuvuissaan ja johtajalla on kansallispuku (ks. kuva 1).

Muutkin pelimannit alkoivat hankkia kansallispukuja vuoden 1973 tienoilla. Virtolaisten esiintyessä Kaustisen kansanmusiikkijuhlilla heinäkuussa 1974 useimmilla soittajista oli jo kansallispuku. Kuitenkin yhdellä soittajalla oli tavallinen puku, eikä nuori kitaransoittajakaan ollut laittautunut kansallispukuun. (Ks. kuva 2.) Kaustisen maakuntateemana oli kyseisenä vuonna Häme, ja virtolaiset esittivät ohjelmakokonaisuuden 'Virtolaisittain'. Tällaisessa tilanteessa ryhmä luonnollisesti halusi tuoda esiin virtolaisuuttaan myös pukeutumisessa. Kaustinen oli ja on varmasti osittain vieläkin areena, jossa eri alueellisuuksia tuodaan kansalliseen, suomalaiseen, valtajulkisuuteen. Tässäkin virtolaiset yhtäältä partikularisoivat, eriyttävät, itseään Virtain puvun avulla muista hämäläisistä pelimanneista. Toisaalta he samalla kategorisoituvat 'virtolaisiksi' ja 'pelimanneiksi'.

Kansallispuvut teetettiin pelimanneille virtolaisena työnä. Kansallispukukankaita tilattiin kotiteollisuuden neuvonta-aseman kautta. Miespelimannien vaimot tai ompelijat tekivät miesten pukujen liivit ja paidat. Paikallinen ompelimo, Leijona-pukine, teki miehille mustat housut. Ryhmän soittajanaiset tekivät pukuja itselleen esimerkiksi kansalaisopiston kansallispukupiirissä. Eräs ryhmän naisista kertoo tehneensä itse kaksikin Virtain pukua - ns. vanhan ja uuden Virtain puvun. ${ }^{2}$ Kaikki ryhmän naiset eivät kuitenkaan tehneet itselleen Virtain pukuja, vaan he saattoivat pitää myös muita kansallispukuja - mitä nyt kukin sattui omistamaan.

Kansallispuvussa ja säännellyissä esiintymispuvuissa voi tietenkin halutessaan nähdä kirjoituksen alussa maalailtuja kunderalaisia univormun piirteitä. Kiinnostava yhtäläisyys tsekkikirjailijan huomioihin on etenkin sillä seikalla, että kansanmusiikin uuden aallon synty ajoittui Suomessa maaseudun kulttuuriseen kriisiin; tulevaisuus todellakin näytti 1960-70-lukujen maaseutupaikkakunnilla kunderalaisen 'kylmältä ja mitään kunnioittamattomalta". Kansanmusiikkiliikkeen kansallispukujen ja Kunderan tarkoittamien univormujen välille ei kuitenkaan voi vetää selkeitä yhtäläisyysmerkkejä. Se olisi determinististä. Mielenkiintoisempaa onkin esimerkiksi Virtain pelimannien kohdalla nähdä, kuinka tätä '"kansallispuku-univormu"'-diskurssia käytetään. Peliman-

2 Terttu Vuorenpään haastattelu syksyllä 1995 ja Jaakko Ahon puhelinhaastattelu kesäk. 1994. "Virtain naisten pukua ei ole niin kovin paljon ihmisillä, sitä [kangasta] on muutettukin rumempaan suuntaan ", kommentoi pelimanni Jaakko Aho. 
nit kun eivät napittaudu siihen vihoviimeistä nappia myöten - liivit alkavat silloin puristaa. ${ }^{3}$

\section{Esimerkki 1. KPL Y 9502/1988}

$\begin{array}{lll}1 & \text { A: } & \begin{array}{l}\text { Sitä rupes radiossa kuunte- kuulumaan aika palijo ja } \\ 2\end{array} \\ 3 & & \text { televisiossakin sitte näytettii näistä (.) jotain pätkiä } \\ 4 & & \text { jostain jostain tilaisuuksista, missä äijät siellä hinkkas } \\ 4 & & \text { kansallispuku päällä ja } \\ 5 & \text { B: } & \text { Ym } \\ 6 & \text { A: } & \text { moni sitten rupes (.) lähtivät käymään esimerkiks } \\ 7 & & \text { Kaustisilla (1.5) taikka jossain semmosissa paikoissa. } \\ 8 & & \text { Olivat intoo täynnä, että eikö täälläkin nyt sentään, } \\ 9 & & \text { kun kerran soittajia on. }\end{array}$

Esimerkissä 1 pelimannien johtaja mainitsee ajanhengen yhtenä ilmaisijana television välittämät tilaisuudet, joissa "äijät - - hinkkas kansallispuku päällä". Paradoksaalisti ilmaistuna: kansallispuku oli 1970-luvun alussa muotia, samaan tapaan kuin 1800-luvun loppupuolella ja toisen aaltonsa (ns. kansallispukuliikkeen) aikoihin ${ }^{4}$, vaikka siitä puhuttiin nimenomaan reaktiona muotia vastaan. "Muotia ei ole ilman tiedotusvälineitä, jotka esittelevät vaatteet ja antavat niille merkitykset", toteavat Marianna Laiho ja Ritva Leino tutkielmassaan Muodikkaan subjektin jäljillä (1987). Itse en kuitenkaan sanoisi tiukasti "merkitykset" vaan merkityksiä. Kukin pelimanniryhmä käytti ilmassa liikkuvia musiikillisia ja kulttuurisia ideoita omiin tarkoituksiinsa. Se mikä tiedotusvälineistä välittyi esimerkiksi Konsta Jylhän ja Purppuripelimannien kautta, oli juuri tuo maaseutukulttuurin vastareaktio maaseudun tyhjenemisen aiheuttamaan kulttuuriseen depressioon. (Laitinen 1977; Kolehmainen ja Saha 1987). Kansallispuku oli jälleen muotia ja samaan aikaan vastareaktio 'kaupunkimuodeille'.

"Miten on mahdollista, että raavaat miehet pukevat helyjä ylleen", muistan Hannu Taanilan ihmetelleen kansallispukuinnostusta jossakussa tuon ajan radio-ohjelmassaan. Ehkä suomalaiset raavaat miehet innostuivat "helyistä"

\footnotetext{
3 Tähän liittyen on syytä mainita, että monet pelimannit mm. teettivät liivinsä huomattavasti pidemmiksi kuin kansallispukuneuvoston ohjeet suosittivat, ja koristeiden käytössä otettiin vapauksia.

${ }^{4}$ Suomessa kiinnostus kansanpukuihin heräsi kahdessa aallossa: 1800-luvun jälkipuoliskolla ja 1900-luvun alussa. Ensimmäisen aallon aktivisteja olivat herrasväen edustajat, virkamiehet jne. Toinen aalto taas kosketti huomattavasti maaseudun elämää. Sivistyneistö heräsi tietoiseksi, yhdessä talonpoikaisnuorison kanssa, pukukulttuurista, ja kansallispukuja alettiin luoda tietoisesti. Kansallispukujen leviämisessä yhdistysliike auttoi merkittävästi. (Lönnqvist 1972, 347.)
} 
juuri vastakulttuurimuodin vuoksi. Ainakin on varmaa, että kansallispuvun merkitykset muuttuivat tai artikuloituivat uudelleen: entistäkin laajemmat kansanryhmät käyttivät sitä tulematta leimatuiksi alkiolaisiksi tai konservatiiveiksi.

Haastattelin yhdessä Helena Ruhkalan kanssa Virtain pelimannien johtaja Rajaa vuonna 1988 - tuolloin kyselimme myös ryhmän vaatetuksesta. Ketään ei pukua pakotettu hankkimaan, pikemminkin suostuteltiin:

\section{Esimerkki 2. KPLY $9505 / 1988$.}

1. HR: Muistatko sää, sillon ku te päätitte ne puvut hankkia, nii

2 minkälaista kommenttia sieltä tuli porukan taholta?

$3 \quad Y R$ : No kyllä ne kaikki, kaikki yleensä halus sen hankkia, että

$4 \quad$ oli yhtenäine vaate, koree vaate.

5 HJ: Kukaa ei vastustanu.

$6 \quad Y R: \quad$ Ei, ei yleensä ja ne jokka, mää sanoin, kaikille, että

$7 \quad$ vaatteilla ei soiteta, joka haluaa hankkia ittelleen korreen

8 puvun, nii sehän käy sitten muissakin juhlissa.

Rajan mukaan kaikki halusivat vaatteen hankkia: "että oli yhtenäine vaate, koree vaate" (3-4). Hän siis korostaa yhtäl̈ltä vaatteen ryhmäidentiteettiä korostavaa, toisaalta esteettistä funktiota. Raja perusteli puvun hankinnan järkevyyttä myös sillä, että puku on käyttökelpoinen juhlapukuna yleensäkin. Johtaja Raja sanoo myös korostaneensa, ettei "vaatteilla soiteta". Samoin ajattelevat useat muutkin virtolaiset musiikinharrastajat . Ruhkala haastatteli vuonna 1989 muitakin virtolaisia musiikinharrastajia ja kyseli heidän kansanmusiikkikäsityksiään, mm. kansallispukujen ja kansanmusiikin yhteenkuuluvuutta. Yleensä vastaajien mukaan musiikki on tärkeämpää kuin vaatteet. Vaikka pukeutuminen olisikin vapaata, vaatteiden on silti oltava siistit, tähdensi joku haastateltavista. (Ruhkala 1989, 79.)

Rajalle kansallispuku oli "yhtenäinen vaate", ja muidenkin Ruhkalan haastattelemien mielestä kansallispuku ratkaisee isojen pelimanniryhmien pulman yhtenäisestä vaatetuksesta: "- - liivipelimanneja tarvitaan arvokkaisiin tilaisuuksiin - - Täälläkin kun pelimanniyhtyeet on isoja ja näyttäviä, niin sillon pitää olla yhtenäinen vaatetus päällä, kun tehdään semmonen estraadihomma." (KPLY 9518, 152). Pukeutuminen siis palvelee paikallistason argumentaatiossa pikemminkin kategorisointia, sitä että kukin pelimanni todella nähdään saman ryhmän jäsenenä, kuin eriyttämistä.

Mielenkiintoista tässä yhteydessä on kuitenkin se, ettei kansallispukudiskurssin menneisyyttä ja paikallisuutta korostava kulttuurinen konteksti (vrt. Jokinen et al. 28) tule esiin lainkaan pelimannien puheessa. Kansallispukujen hankintaa ei voikaan suoraa päätä ja yksinomaan rinnastaa nostalgiaan. Ainakin täytyisi kussakin tapauksessa miettiä asiaa erikseen: mitä puku näille pelimanneille itselleen merkitsi? Heikki Laitinen on vastaavasti todennut 
Kaustisen kansanmusiikkifestivaaleista, että ne olivat maaseudun eläjän kulttuurinen protesti, moderni ja rationaalinen reaktio (1977, 82-84 ja 1989).

Moderniin reaktioon saattaa kuitenkin liittyä nimenomaan menneisyyden ja paikallisuuden aktualisoituminen - juuret ovat tärkeä osa kansallispuvun viestiä. Pelimanniryhmät merkittyivät alusta lähtien topologisesti, paikkakuntien mukaan. Tämä näkyy jo pelimanniryhmien nimistä. Kun siis Virtain pelimannit ottavat käyttöönsä 'Virtain puvun', he ottavat osaa myös kulttuuriseen repertuaariin, jossa Virtain puku viittaa 'muinaiseen' paikallisuuteen. Tällaiset seikat ovat "puvun merkkejä", jotka Bogatyrevin mukaan on opittava, kuten kielikin opitaan. Kansallispuvun perusmerkkikielen ovat epäilemättä lähestulkoon kaikki suomalaiset varttuessaan oppineet. Kuten Lönnqvist $(1979,23)$ toteaa, olemme jo lapsesta lähtien vähitellen oppineet käyttämään eri symboli- ja arvojärjestelmien vaatteita. 'Kutakin elämän teatterinäyttämöllä esitettävää uutta roolia varten yhteiskunnalla on jo valmiiksi tarjottavana 'oikeat vaatteet'." (ibid.)

Virtain pelimanneillekin oli varmasti selvää, mikä tunnuskuvallinen arvo kansallispukuun sisältyi heidän pukeutumisjärjestelmässään (vrt. Lönnqvist mt. 21). 1970-luvun muoti artikuloi vanhoja, välillä 'nukkuneita' (vrt. Elias 1978) pukeutumisen elementtejä omalla tavallaan. Tuloksena syntynyt artikulaatio ei ole jäännöksettä palautettavissa vanhaan kansallispukudiskurssiin: se on yhdistelmä vanhoja ja uusia merkityksiä. Näin Bogatyrevin luokituksista yksikään ei käy sinänsä, vaan vaatetuksen merkitykset rakennetaan esteettisten, käytännön, paikallisuuden ja ryhmäyhteenkuuluvuuden aspektien kautta. Tämä käy ilmi myös pelimannien puhuessa puhuvat uudemmista esiintymisvaatteistaan.

\section{Siniset liivit ja harmaat housut}

Kun menin mukaan ryhmän toimintaan havainnoitsijana vuonna 1988, ryhmä ei enää kovin usein käyttänyt kansallispukuja. Esiintymisasu oli seuraavanlainen: harmaat suorat housut, vaaleansininen kauluspaita ja tummansininen trikoosamettiliivi. Viimeksi mainittu oli tilattu parkanolaiselta valmistajalta ja siinä oli vasemmassa rinnuksessa vihreänä kohopainatuksena ryhmän jäsenen piirtämä logo : teksti 'Virtain pelimannit' ja nuottiavain. Asu oli sama niin miehillä kuin naisillakin. Se oli selvästikin enemmän miehisillä ehdoilla tehty: liivi-pukupaita-housut-yhdistelmää on totuttu pitämään rennon siistinä miehen asuna.

Seuraava keskustelu käytiin kun pelimannit olivat menossa kansalaisopiston pikkujouluihin, tanssin soittajina. Johtaja (A) otti esiin esiintymisvaatteet ja pelimannit neuvottelivat niistä. Tässä aluksi koko keskustelu: 
Esimerkki 3. Y 9616. A: Piirin johtaja; B, C, E: pelimanneja; D: pelimanniyhd. johtaja. $^{5}$

$1 \quad$ A: $\quad$ Viikon päästä kakskymmentä kolomekymmentä sielä

2 (0.8) sovitaanko vaatteet= pannaanko livit (1.5)

3 sininen livi

$4 \quad$ B: $\quad$ ((hiljaisia keskustelun ääniä))

5 A: ollaan yhtenäisiä=

$6 \quad C: \quad=$ Sehän on sitä varten

$7 \quad A: \quad T \ddot{a}$

$8 \quad$ C: $\quad$ Sehän on sitä varten [se livivi

9 A: [*niin on* (1.5)

10 A: ( ) ravatitta tai ravatilla. ASIA

11 SELEVÄ.

12 D: Se pitäs muuten joskus sopia kans (1.0) se asia (1.0)

13 ravatilla vai ravatitta ()

14 C: Ravatti tiukalla nii ei pääsis hulluus muuhun ruumiiseen

15 ähhäh häh (nauraa)

16 Muut: (Naurua)

17 D: Ollaan ravatitta niin kauan ku ostetaan ravaTIT (0.5)

18 sovitaanko näin

19 E: Niin samanlaiset

20 D: Ym. Niin kauan ollaan [ravatitta kunnes ostetaan

21 yhtenäiset ravatit

$22 E$ :

$$
\text { suikaletta (---) }
$$

[joku kutos semmosta kapeaa

${ }^{5}$ Lyhenteet ja litteraatiosymbolit :

KPL Y Tampereen yliopiston kansanperinteen laitoksen yleiskokoelmat

KPK Kenttäpäiväkirja (kirjoittajan hallussa).

(.) Lyhyt tauko.

() Tauko (mitatut: kymmenesosasekunteina).

(--) Poisto.

(()) Litteroijan huomautus.

[ Päälekkäistä puhetta.

$=\quad$ Välittömästi edeltävän puheen jälkeen.

alleviivattu Äänenkorkeuden tai voimakkuuden avulla aikaansaatu korostus.

: : Pidentynyt äänne

ISO KIRJAIN Ympäristöönsä nähden kuuluvammin.

** Ympäristöönsä nähden hiljaisemmin.

- $\quad$ Puhuja jättää kesken

\# \# Narisevalla äänellä. 
Johtaja kysyy ryhmältä, 'sovitaanko vaatteet', mutta tarkentaa kysymyksen välittömästi tarkoittamaan nimenomaan sitä, 'pannaanko liivit'. Pelimanneilla olisi mahdollisuus vastata kysymykseen jo tässä vaiheessa, tauon aikana (rivi 2), mutta kysymys-vastaus-vierusparin toista osapuolta saadaan odottaa riville 6 asti. Johtaja tarkentaa rivillä 3 tarkoittavansa nimenomaan sinistä liiviä, miehet keskustelevat hiljaa keskenään ja johtaja ehtii tuoda esiin vielä syynkin liivien käyttämiseen: 'ollaan yhtenäisiä' (rivi $5)$.

Johtaja joutuu usein kiinnittämään pelimannien huomion huutelemalla 'hei, kuulkaa' tai vastaavaa - tämä on signaali, joka vastaa sinfoniaorkesterin kapellimestarin tahtipuikon napautusta nuottitelineeseen. Tässä johtaja ei esitä kysymystä erityisen painokkaasti, mutta vastaus tulee silti kohtuullisen nopeasti. C on ollut valmiina vastaamaan jo ennen yhtenäisyysfunktion mainitsemista, sillä hän aloittaa puheenvuoronsa lähes päällekkäispuhuntana johtajan kanssa. Vastaus, 'sehän on sitä varten', ilmaisee, että A on kysynyt C:lle itsestään selvää asiaa. Liivit on muutamaa vuotta aiemmin hankittu esiintymisiä varten ja nythän on tulossa esiintyminen.

On kuitenkin mielenkiintoista, miksi johtaja kuitenkin kysyy liivien laittamisesta. Yksi selitys on siinä, että kyseessä on kansalaisopiston sisäinen pikkujoulujuhla, jossa ei ole välttämätöntä osoittaa ryhmämäisyyttä pukeutumisella sillä tavoin kuin ulkopuolisille esiinnyttäessä. ${ }^{6}$ Johtaja tuo tämän kysymyksen neuvoteltavaksi, vaikka itse kallistuu liivien kannalle (rivi 5).

Tässä neuvotellaan siitä, pitääkö pikkujouluihin pistää päälle le costume, institutionaalinen puku, vai riittääkö l'habillement, yksilölliset vaatteet: lopulta argumentoidaan kategorisaation puolesta partikularisaatiota vastaan ja päädytään institutionaaliseen pukuun. Johtaja myöntää liivin olevan esiintymistä varten ja puolentoista sekunnin tauon jälkeen hän vetää asian yhteen (rivi 9). Sanamuodoista ei saa selvää, mutta loppukaneetti on: 'ravatitta tai ravatilla', jonka jälkeen vielä kovalla äänellä lopetukseksi 'ASIA SELEVÄ'.

Ryhmä keskusteli talven 1988-89 mittaan useampaan otteeseen solmion hankinnasta. Näin myös käsiteltävänä olevassa keskustelussa:

\footnotetext{
${ }^{6}$ Esimerkiksi kaksirivisten ohjaaja Airi Hautamäki ei ollut pukeutunut kansallispukuun vaan kiiltäväkankaiseen iltajuhlapukuun. Samaten hänen ohjaamiensa ryhmien lapset ja aikuiset olivat pukeutuneet tavallisiin juhla-asuihinsa. (KPK 47:48). Hautamäki on kuitenkin korostanut nimenomaan sitä, että kansallispuvut ovat hänen ryhmissään tärkeitä esiintymisasuja (Riihola 1995, 117).
} 


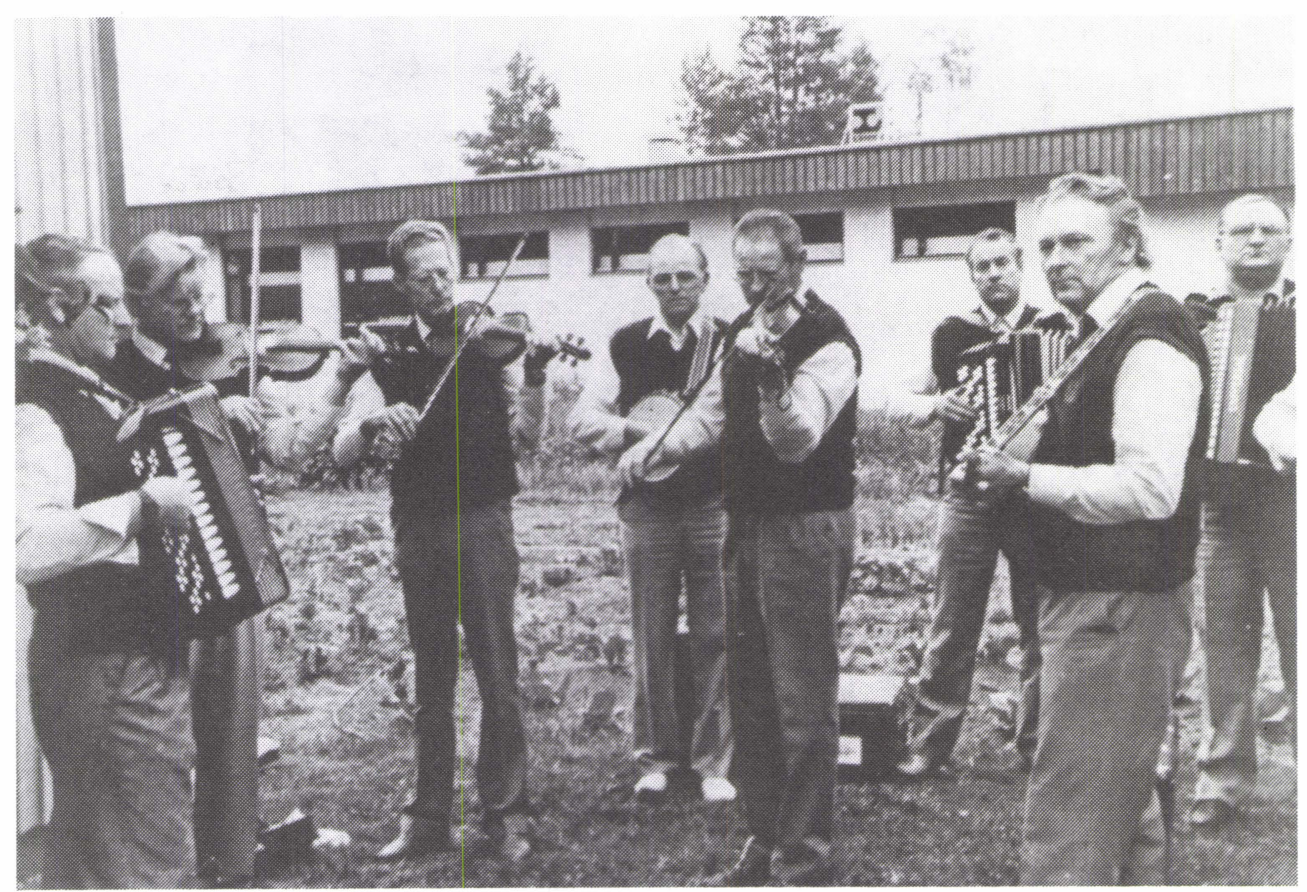

Kuva 4. Virtain päivillä 1980-luvun puolivälin jälkeen. Esiintymisasuna siniset liivit, harmaat housut, muttei solmiota. Kuvan omistaa Yrjö Raja.

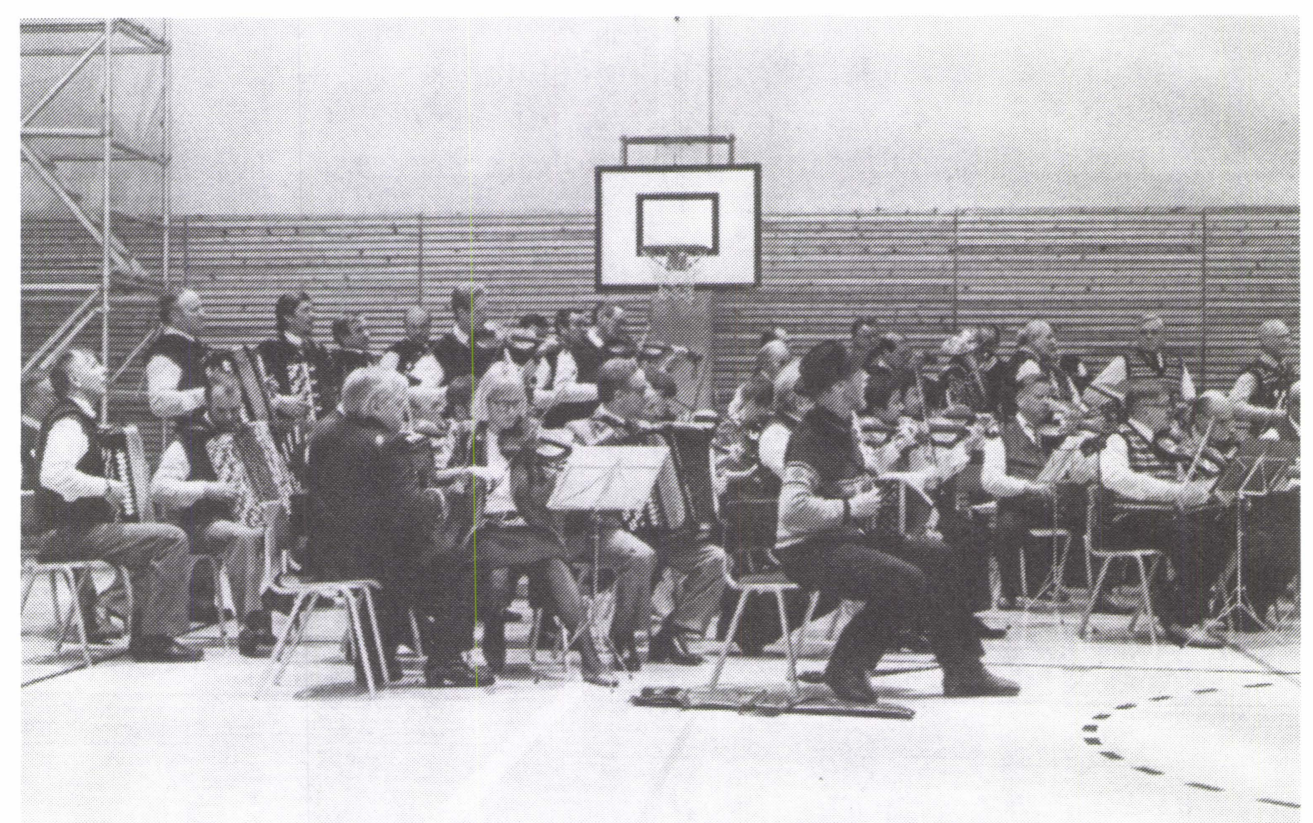

Kuva 5. Viininpunainen nahkasolmio ensimmäistä kertaa käytössä Vilppulan Pelimannitalkoissa maaliskuussa 1989. Virtain pelimannit takana vasemmalla. Kuva H. J. 


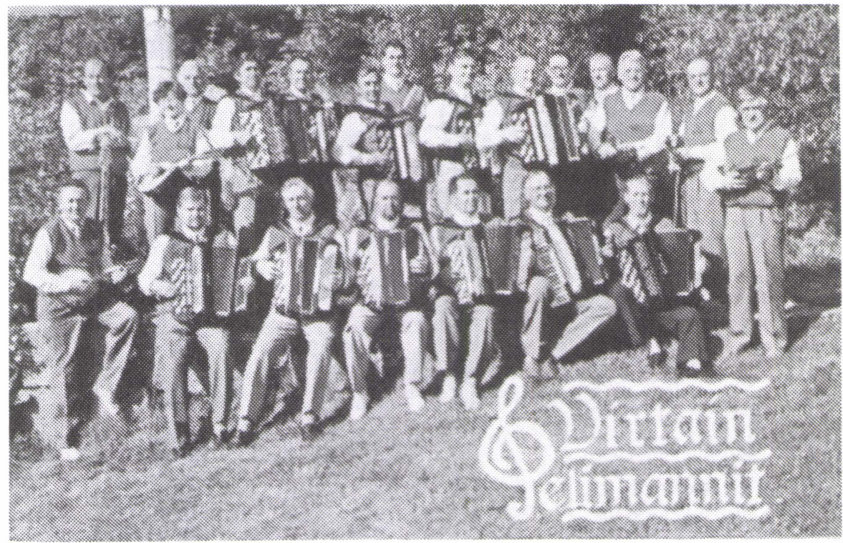

Kuva 6. Esiintymisasu vuonna 1993: punaiset liivit, harmaat housut ja solmio sekä raidallinen paita. Oikeassa alakulmassa näkyy myös logo. Kuva on pelimannien kasetin kannesta.

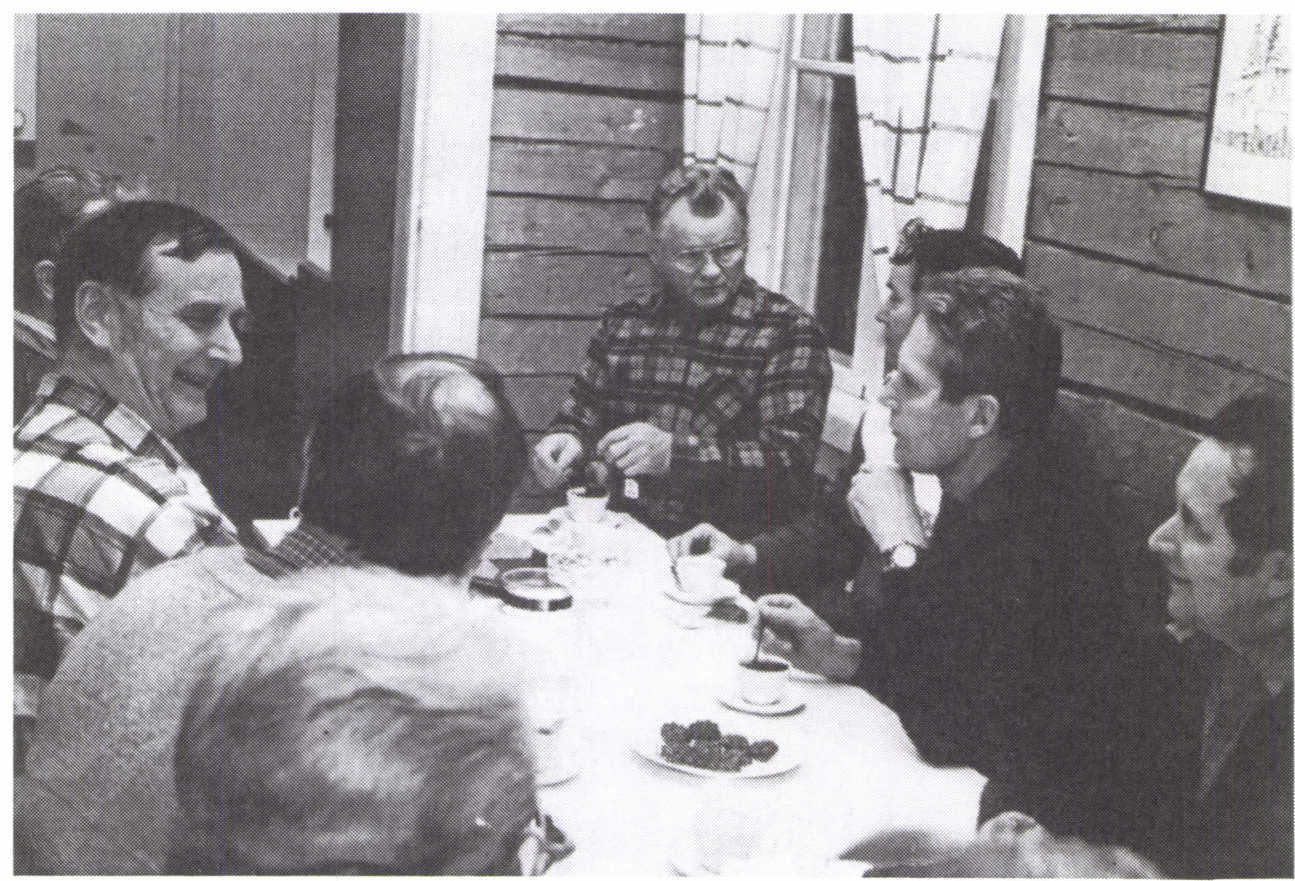

Kuva 7. Harjoitusten kahvitauko. Harjoituksiin ei tälläydytä. Harjoituspaikka, kansalaisopiston veistosali, on olohuoneen jatke: sinne saatetaan tulla jopa tohveleissa. Nuorelta näyttämisen pakkoa ei ole. Kuva H. J. 


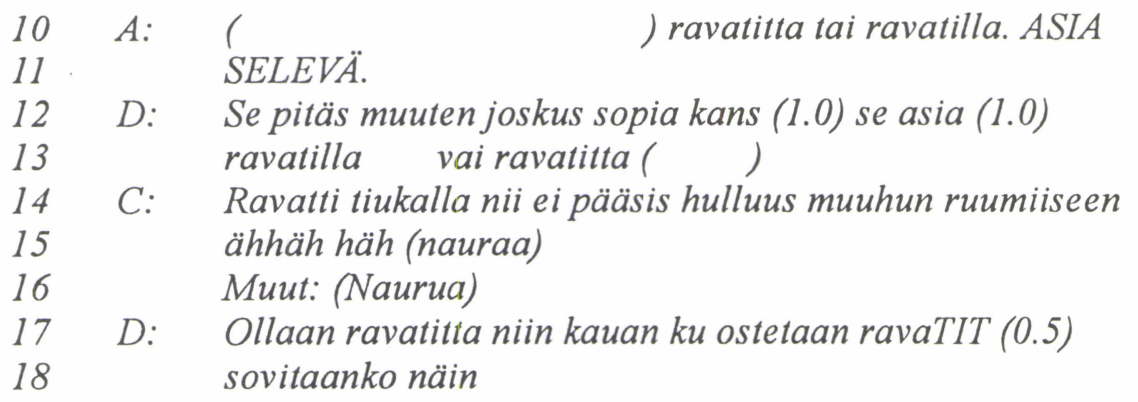

Johtaja tuo kravattiasian esiin, mutta vain aikaisemman käytännön mukaisesti: pelimannit valitsevat itse, haluavatko pitää kravattia esiintyessään. Pelimanniyhdistyksen puheenjohtaja kuitenkin jatkaa keskustelua, ilmeisen lopetuslausahduksen jälkeenkin. Hän lunastaa puhumisen oikeuden tuomalla asian esiin 'muuten' sanan kautta, joka saa asian kuulostamaan lisäykseltä edelliseen - kuulija saa valita, ottaako asiaan kantaa vai ei; asiasta pitäisi sopia 'joskus', ei välttämättä heti (rivit 12-13). Kyseessä on kuitenkin selvä ehdotus: ei ole aivan yhdentekevää, esiinnytäänkö kravatin kanssa vai ilman. Sekalainen seurakunta on huonompi vaihtoehto.

C käyttää huulenheiton tilaisuutta heti hyväkseen (rivi 14), ja nauraa itse vitsilleen - toiset seuraavat perässä. Puhe pukeutumisesta kietoutuu tässä puheeseen miehisestä ruumiillisuudesta - ja henkisyydestä. Mikäpä olisikaan miehen ruumiillisuuden ja sen hillitsemisen kannalta mielenkiintoisempi vaatekappale kuin juuri solmio? Minä ainakin yhdistän solmion kulttuurisen tietämykseni perusteella asiallisuuteen ja itsehillintään, en hulluuteen. Pelimanniryhmä tekee ilman solmiota rennomman vaikutelman kuin solmion kera. Kravatti laittaa miehet aisoihin aivan kuten nenärengas sonnin. C:n esittämä huuli leikitteleekin tässä merkitysten kentässä. Yhteinen nauru riittää vastaukseksi ja D palauttaa asiallisen diskurssin välittömästi. Hän ehdottaa ratkaisuksi esiintymistä kravatitta siksi kunnes kravatit on ostettu.

$\begin{array}{lll}18 & & \text { sovitaanko näin } \\ 19 & \text { E: } & \text { Niin samanlaiset } \\ 20 & \text { D: } & \text { Ym. Niin kauan ollaan [ravatitta kunnes ostetaan } \\ 21 & & \text { yhtenäiset ravatit } \\ 22 & \text { E: } & \text { [joku kutos semmosta kapeaa suikaletta (---) }\end{array}$

Puheenjohtajan elkein D kysyy (rivi 18), 'sovitaanko näin'7; E korjaa ehdotusta tarkentamalla kravatit 'samanlaisiksi' (rivi 15), jolloin D toistaa ja korjaa muotoiluaan 'yhtenäisiksi ravateiksi'. E:n ajatus yhtenäisen suikaleen kutomisesta jää jo yleisen keskustelun ja johtajan puheenaiheen vaihtamisen alle.

\footnotetext{
${ }^{7}$ Koska videokuvaa ei ole käytössä, en tiedä, ilmaisivatko pelimannit mielipiteensä asiasta elein vai eivät. Sanallisesti he eivät sitä tee.
} 
Punaisena lankana tässä keskustelussa näyttää olevan pukeutumisen yhtenäisyys. Pelimannin kategoriasidonnaisiin piirteisiin ei suinkaan kuulu sen kummemmin kravatin pitäminen kuin kravatittomuuskaan: sen sijaan yhtenäistä ulkoasua pidetään tavoiteltavana. Kaulasomiste ei kuitenkaan voi olla minkälainen tahansa, kuten myöhemmin kävi ilmi. Seuraavassa ote kenttäpäiväkirjastani, jonka kirjoitin pelimannien joulukuussa järjestämistä iltamista Virtain Kisapirtillä. Kahvipöydässä viritin keskustelua solmiosta:

\section{Esimerkki 4. KPK 63:67}

1 (--) Kysyin, etteikö kravattia ole saatu vielä hankittua. Ei

2 kuulemma. Ehdottelivat värejä. Harmaata. Punaista! Omana

3 kantanani toin esiin, että sen pitäisi olla näkyvä. Kysyin -

$4 \quad$ miksei rusettia? Synkkäkulmainen mies vastusti tosissaan.

5 Tarmo selitti, että se vinksottaisi. "Pitää puhua, tuoda esiin

6 rusettiasiat ja muut", sanoi Ala-Kulmala pilke silmäkulmassa

7 noustessaan. "Älä vaan tuo", sanoi tumma mies.

$8 \quad H o u s u t$ oli tilattu, niin pitäisi kravattikin. 'Ei mistään löydy

9 semmosta määrää kravatteja valmiina Virroilta."

Tässä luovun hetkeksi tarkkailevan etnografin roolistani ja tuon esiin (4) tahallisesti rusettivaihtoehdon - tietoisena siitä, ettei se äkkiseltään tunnu sopivan pelimannien pukeutumiseen. Keskustelualoitteeni otetaan vastaan: kolme miestä lukee ehdotustani eri näkökulmista käsin ja vastaa niiden mukaisesti. 'Synkkäkulmainen' mies ottaa lausumani vakavana ehdotuksena ja katsoo aiheelliseksi sen selkeän tuomitsemisen - rusettiajatus sotii voimakkaasti vastaan hänen näkemystään pelimanniryhmän estetiikasta. Tarmo vastaa myöskin ehdotukseeni siltä pohjalta, että olin saattanut esittää sen tosissani. Hänenkin kantansa on kielteinen (5) ja perustelut käytännöllis-esteettiset (rusetin vinksottaminen). Ala-Kulmala sen sijaan ottaa lausumani myös kutsuna huumoriin. Osittain hänen on mahdollista tehdä näin nimenomaan siksi, että edellisissä puheenvuoroissa on tietynlaista tosikkoutta, joka suorastaan kutsuu huulenheittoon. Pelkkänä lausumana hänen kommenttinsa voitaisiin myöskin lukea 'totena pitämisen'-repertuaariin, etenkin kun siinä ehdotetaan suorastaan kokousmaista asian yhteiskäsittelyä: 'Pitää puhua, tuoda esiin rusettiasiat ja muut" (5-6). Tapa jolla Ala-Kulmala asian esittää - pilke silmäkulmassa kuitenkin osoittaa, että hän näkee tilanteen huvittavana.

Pelimanneille ei olisi edes tullut mieleen keskustella rusetin hankinnasta, ellen minä, ryhmän hyvin marginaalinen jäsen, olisi tuonut asiaa esiin. (Asiasta ei sen koommin keskusteltu.) Ala-Kulmalan lausuman huumori nouseekin tästä: näennäisen asiallinen ajatus 'rusettiasian' esiintuomisesta on niin epätodennäköinen, että se rakentuu huuleksi. 'Tumma mies' ei kuitenkaan lue tilannetta samoin kuin minä, vaan liikkuu edelleen vakavassa diskurssissa ja 
tähdentää aivan tosissaan: "älä vaan tuo" (rivi 7), ikään kuin jo ajatus jatkokeskustelusta olisi vastenmielistä.

Pelimanniryhmä ottaa pukeutumisellaan kantaa pelimannin kategoriaan ja erottautuu tälläkin tavoin muista muusikkoryhmistä. Rusettejä käyttävät muita musiikinlajeja edustavat muusikot: viihdemuusikot tai vaikkapa osa jazzmuusikoista. Kun menin eräänä pelimannien harjoitusten jälkeisenä päivänä virtolaisiin jazz-jameihin, pianon ääreen asteli ryhmän johtaja "jännittävästä jazzmaailmasta"8, "hopeariipuksineen, poolop(aitoineen) \& kultasormuksineen valmiina yökerhoon". Jos pelimanni pukeutuisi edellä mainittuihin tamineisiin, frakkiin tai vaikkapa rusettiin, hän olisi vähintäänkin selityksen velkaa yleisölleen.

Rusettiehdotuksen saamat reaktiot osoittavat, että ryhmällä on tarkka esteettinen tietoisuus siitä, mikä kuuluu pelimannin pukeutumiseen. Simon Frith onkin väittänyt, että kategorioiden tietynlainen sekoittuminen saa ihmiset hyvin usein pitämään musiikkia huonona: rockpiirien edustajista on naurettavaa, kun Telly Savalas laulaa Bob Dylania (tai Matti Salminen Juicen "Viidettätoista yötä"). ${ }^{9}$ Rusettimuusikkokategorian ja pelimannimuusikkokategorian sekoittaminen saa pelimannit samalla tavoin kavahtamaan.

Solmio-ongelma sai ratkaisunsa maaliskuussa 1989. Pohjoishämäläisten pelimannien vuorottain järjestämissä Pelimannitalkoissa Vilppulassa Virtain pelimannit käyttivät ensimmäisen kerran uusia, viininpunaisia nahkasolmioitaan.

${ }^{8}$ Olen kiitollinen Dr. Bruce Johnsonille keskusteluista, joita kävimme tästä aiheesta: KPK 215:284 pelimannien harjoitukset 23.2.94

(--) Puhuimme B(ruce)n kanssa - hän vertaili swing-bändiä \& pelimanneja ja totesi että pelimannit eivät elä "jännittävässä jazzmaailmassa" (vrt. Tomas hopeariipuksineen, poolop(aitoineen) \& kultasormuksineen valmiina yökerhoon) (---). Pelimanneista Herkko tohveleissa (minun huomioni), samoissa tohveleissa kotona ja siellä, ei niin suurta eroa, ei "nuorelta näyttämisenä".

Palaan toisessa yhteydessä viimeisenä mainittuun teemaan: luontevaan vanhenemiseen vs. nuorelta näyttämisen pakkoon.

${ }^{9}$ Simon Frithin mukaan tämän tapainen taidemuotojen sekaantuminen on yksi tapa perustella sitä, miksi jokin musiikki on huonoa. Huonoa musiikkia sinänsä ei ole olemassakaan. Huono ja hyvä musiikki syntyvät perustelujen, argumentoinnin tuloksena. (Frith 1994; myös Järviluoma 1994.) 
Esimerkki 5. KPK 152:197; Soittotalkoot Vilppulan urheilutalolla 4.3.89 (pukuhuoneessa odotellessa).

$1 \quad$ Huomasin, että miehillä oli hyvin sinisiin samettiliiveihin

2 sointuvat viininpunaiset nahkasolmiot. Vieressä istuva

3 nainen kertoi, että ne olivat käytössä ensi kertaa. Kalle oli ne

4 hankkinut. Naisen mielestä on ollut harmillista, kun yhteistä

5 solmiota ei ole ollut. Myös Annalle ja Herkolle (tulivat omilla

6 autoillaan, myöhästyivät lähdöstä) jaettiin solmiot. He

7 laittoivat solmu(kkee)n ja sitten solmion kaulaansa. (Arvo

8 haisteli myöhemmin omaansa usein, aidon nahan tuoksu.)

9 Pelimanneilla oli samat siniset paidat ja vaaleanharmaat

10 housut kuin ennenkin esiintymisissä. Vain isolla Ollilla oli

11 musta neuleliivi, Veikolla sininen villapaita.

Päiväkirjassani toin solmioasian esiin oman esteettisen näkemykseni kautta: totean, että solmio sointuu hyvin yhteen sinisten samettiliivien kanssa (1-2). Keskustelin asiasta ulkopuolisen, miespelimannin vaimon kanssa, jonka mielestä yhteisen solmion puuttuminen on ollut "harmillista". Pelimannit ottivat solmiot vastaan ilmeisen tyytyväisinä. Ne eivät miellyttäneet ainoastaan näköaistia, vaan myös aidon nahan tuoksu pantiin merkille (7-8). Myös ainoa ryhmässä tuona ajankohtana vakituisesti soittanut nainen otti solmion, miehisen asusteen, muitta mutkitta vastaan ja käytti sitä siitä lähtien siinä missä muutkin. Ryhmän yhtenäisyyden vaatimus siis ohitti sukupuolten perinteiset erottelutottumukset.

Kun menin muutaman vuoden tauon jälkeen tapaamaan pelimanneja vuonna 1993, esiintymisasu oli osittain vaihtunut. Sininen samettiliivi oli vaihtunut punaiseen, samasta materiaalista tehtyyn liiviin ja nahkasolmio harmaaseen kangassolmioon. Housut olivat samat harmaat suorat housut, mutta paita oli vaihtunut valkoiseen, ohuilla punaisilla raidoilla kuvioituun malliin. Tapaukseen reagoitiin puolin ja toisin, huumorilla. Pelimanniyhdistyksen puheenjohtaja ojensi ryhmän tekemän kasetin kannesta otetun laserkopiosuurennoksen, jossa pelimannit poseeraavat soittimineen ja uusine pukuineen (ks. kuva 6). Ojentamista edeltää 'puhe': 
Esimerkki 6. KPL Y numeroimaton/1993.

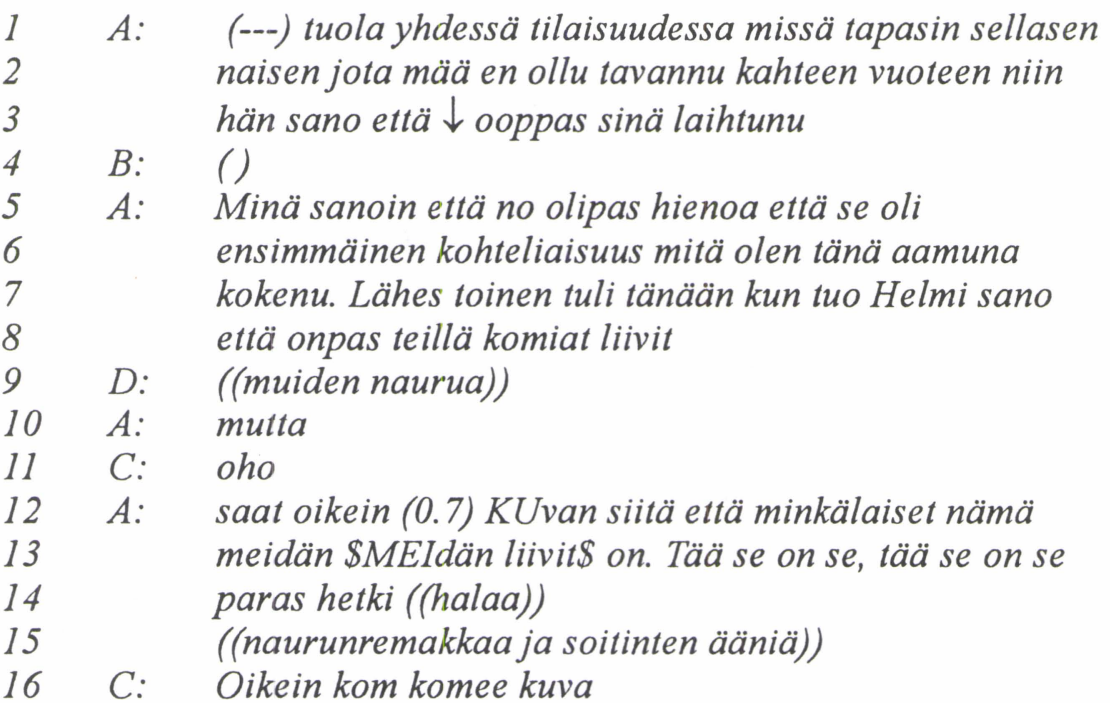

Neutraalia tarkkailijatutkijuutta suosivat kollegat saattaisivat tässä yhteydessä valitella sitä, että tutkijana olen mennyt pilaamaan aineistoa ja höläyttämään ensimmäiseksi oman esteettisen arvioni pelimannien uudesta vaatekuosista (rivit 7-8): olisinhan voinut vain todeta uudet liivit ja vaivihkaa kartoittaa ryhmäläisten näkemyksiä niistä. En ollut enää niin varautunut tarkkailija kuin tutkimukseni alussa, ja käyttäydyin lähes kuten olisin käyttäytynyt missä tahansa sosiaalisessa tilanteessa, jossa tapasin vanhoja tuttuja.

Olin myös aidosti sitä mieltä, että punaiset liivit tekivät pelimanniryhmästä pirteän näköisen; ne kiinnittivät melkoisesti huomiotani. A käyttää lausumaani välittömästi hyväkseen ja nimeää sen kohteliaisuudeksi (rivit 6-7). Samalla hän välittää kohteliaisuuden koko ryhmälle, vaikka aloittaakin puheensa paralleelilla kertomuksella, jossa nainen on lausumassa kohteliaisuutta hänelle itselleen: "ooppas sinä laihtunu" (rivit 1-7). Kummassakin tarinassa liikutaan miehisen keho- tai 'ruumis'puheen kehyksessä. Tavallaan samassa fyysisessä repertuaarissa liikutaan myös silloin, kun A ojentaa minulle "oikein KUvan siitä että minkälaiset nämä meidän \$MEIdän liivit\$ on" (rivit 12-13) ja halaa minua sanoen: "Tää se on se, tää se on se paras hetki"'(13-14).

Minulle siis annetaan lahja, ja hyvän puheenpitäjän taidolla A luo puheeseensa monia merkitystasoja yhtäaikaa. Kulminaatiopisteessä hän ojentaa lahjan, musiikkikasetin kansikuvakopion, kasetin, josta pelimannit ovat ylpeitä. Koska olen kiinnittänyt huomiota pelimannien vaatteisiin, lahjan antaminen puetaan niin, että se samalla liittyy minunkin kiinnostukseni kohteisiin: saan kuvan kehumistani liiveistä. Eivätkä ne ole A:n puheessa mitkä tahansa liivit vaan 'meidän \$MEIdän liivit\$'. Tässä tutkijalle suunnatun puheen kautta uusinnetaan ja rakennetaan ryhmän identiteettiä: tutkijan komeiksi kehumat 
liivit rakennetaan toiston ja voimakkaan korostetulla, hymyilevällä äänenpainolla nimenomaan 'MEIdän' liiveiksi.

Tätä kautta todentuu jälleen kerran: ryhmä on ryhmä. Mutta on syytä hieman tarkastella, miten ja miksi tämä todennetaan esimerkissä 6. Tutkija kiinnittää alun perin 'subjektiensa' huomion identiteettityöhön, jota nämä pukeutumisen avulla tekevät aivan luonnollisesti ja siitä melua tekemättä osana toimintaansa. Tutkija tuo tätä esiin, ja pinnalle tulevat asiat saattavatkin vaikuttaa tutkimuksen subjekteista huvittavalta. A:n puheen sävy on humoristinen: minulle tulee kuva, että lausuma on identiteettikonstruktio, joka saattaa tutkijalle olla 'vakavampi' kuin heille itselleen.

Samaan tapaan antropologi Michael Moermanin pelkkä läsnäolo sai thaimaalaiset luet tuomaan esiin etnistä identiteettiään, sitä miten he poikkesivat alueen muista heimoista $(1975,65-66)$. Normaalielämässä tällaiset identiteetin puolet eivät usein tulleet ajankohtaisiksi. Moerman oli tullut tutkimaan nimenomaan "etnistä identiteettiä": tämän käsitteen avulla hän raportoi, säilöi ja analysoi inhimillisiä ilmiöitä. Niinpä hän ohjasi ihmisiä, jotka hänelle puhuvat, kiinnittämään ensisijaisesti huomiota etnisiin kategorisointeihin. Moerman kertoo esimerkin hautajaisista, joissa Yuan kaupunkilaisnainen kertoi vainajan kuuluvan shaneihin. Jos vieras ei olisi ollut nimenomaan kiinnostunut siitä keitä luet ovat, hänen kategorisointinsa ei luultavasti olisi ollut etninen. Ehkä hän olisi kertonut vainajan sukulaisuudesta, rikkaudesta tai naapureista, sillä kaikkia näitä kategoriajoukkoja käytetään Chiengkhamissa yhtä lailla kuin etnistäkin osoittamaan ryhmiinkuulumista. Minä kiinnitin A:n huomion pukeutumiseen, ja hän käytti johdonmukaisesti samaa pukeutumisdiskurssia antaessaan lahjaa ryhmän nimissä ja puhuessaan ryhmästä.

"Meidät liivit" lausuma on myös hieman ironinen, sillä punaiset liivit eivät suinkaan miellyttäneet kaikkia ryhmäläisiä. Haastattelemani pelimanni ei ollut varma, miksi sininen liivi ylipäätään piti vaihtaa. (Todennäköisesti se oli ollut käytössä jo liian kauan.) Liivin valinnassa hinta oli joillekuille aivan ratkaiseva tekijä. Kun kangasmalleja katseltiin, "kankaiset", so. esimerkiksi kansallispukua muistuttavat materiaalit, tuntuivat toisista liian kalliilta: puku "ei saisi maksaakaan". Punaiseen liiviin päädyttiin hieman yllättäen. Haastateltavani kuului niiden vastustajiin, mutta piti kuitenkin suunsa kiinni, koska hänen mielestään pitää tyytyä enemmistön päätökseen.

\section{Miksi samettiliivit syrjäyttivät kansallispuvun}

Pelimannit pitivät kansallispukuja 1980-1990-lukujen vaihteessa vain harvoin. Yksi proosallisimmista syistä oli se, että ikääntyvä ryhmä ei todellakaan enää mahtunut kaksikymmentä vuotta sitten hankkimiinsa pukuihin, "ei mahdu liivi kiinni". Nuoremmilla ryhmän jäsenillä ei edes ollut kansallispukuja, ja vanhemmat pelimannit olivat antaneet niitä eteenpäin, mm. tanhuajil- 
le. Kun pelimannit vuoden 1994 tienoilla puhuivat kansallispukuihin pukeutumisesta, he totesivat, ettei pukuja enää tahdo löytyä. Vuotta myöhemmin tilanne oli jo muuttunut. Pelimannit hankkivat kansallispukuihinsa uusia osia puuttuvien ja pieniksi käyneiden tilalle. Nähtäväksi jää, ryhtyvätkö he pukuja myös käyttämään.

Vuonna 1989 pelimannit keskustelivat pukeutumisesta Isojoella pidettäviin Eteläpohjalaisiin Speleihin seuraavasti:

Esimerkki 7. KPL Y, vuosi 1989 . C: Piirin johtaja; I, J, K, A: pelimanneja.

$\begin{array}{lll}1 & \text { I: } & \text { Pannaanko sinne kansallispuku? } \\ 2 & \text { J: } & \text { (nauraa) } \\ 3 & \text { K: } & \text { Ei takuulla laiteta }= \\ 4 & \text { C: } & \text { =Ei tiärä viälä sannoo, tuskimpa } \\ 5 & \text { A: } & \text { Ei tiärä viälä }(0.8) \\ 6 & \text { C: } & \text { Tuskinpa vaan }(1.0){ }^{*} \text { mullon ainaki nuo livit, liivit } \\ 7 & & \text { kutistunu* } \\ 8 & & \text { Useat: (naurua) }\end{array}$

Kansallispuku "kummitteli" kuitenkin edelleen keskusteluissa, se on olemassa pukeutumispuheen tasolla, yhtenä repertuaarina, joka pulpahti aineistosta silloin tällöin esiin. Edellisessä lainauksessa yksi rivipelimanneista mainitsee puvun ja saa heti toisen jäsenen nauramaan Kolmas taas vastaa selkeän kielteisesti: ei takuulla laiteta (rivi 3). Piirin johtaja tosin jatkaa välittömästi K:n jälkeen hieman epävarmemmin, passiivia käyttäen, "ei tierä vielä sannoo", mutta lisää varovaisen pessimistisen "tuskimpa"-sanan loppuun. Pelimanni A toistaa johtajan ilmauksen alkuosan, joka jättää vielä kansallispuvuillekin mahdollisuuden (5). C täydentää itse tähän pienen tauon jälkeen A:n poisjättämän osan, "tuskinpa vaan" ja antaa asialle omakohtaisen selityksen: liivit ovat kutistuneet (6-7). Huomio rakentuu humoristiseksi, useat pelimannit nauravat tämän jälkeen.

Vatsakummun ilmaantuminen on ikääntyvän suomalaisen miehen tyypillinen vartalonmuutos. Vaatetuksesta puhuttaessa pelimannit puhuvat omasta kehostaan ja sen muutoksista, usein huumorilla. Johtaja ei siis suinkaan sano, että on pyöristynyt vuodesta 1973, vaan ilmaisee asian kiertäen; humoristisessa ilmauksessa kieltämällä myönnetään oman kehon muutos. Nauru (rivi 8) saattaa osoittaa sitäkin, että kyseessä on jaettu kokemus; viesti ymmärretään.

Oma ruumiinkuva ei suinkaan ole merkityksetön asia, ja eri musiikillisissa diskursseissa ihannevartalot ovat erilaisia. Yksi pelimannidiskurssin piirre on se, että se antaa tilaa - ainakin miesten ${ }^{10}$ - "arvokkaalle vanhemiselle",

${ }^{10}$ Miesten ja naisten ruumiillisuudesta puhutaan ryhmässä eri tavoin. (Vrt. Järviluoma [painossa].) 
nuorelta näyttämisen pakkoa ei ole. Harjoituksiin voi tulla kaikessa rauhassa vaikka kotitohveleissa (ks. alaviite 7) aivan kuin kansalaisopiston veistosali olisi olohuoneen jatke.

Seuraavassa ote kenttäpäiväkirjastani.Edellä, esimerkissä 7pelimannit keskustelivat siitä, miten pukeutua kansalaisopiston pikkujouluihin. Tässä keskustelen kyseisissä pikkujouluissa, Virtain hotelli Tarjanteessa, yhtyeen johtajan kanssa esiintymisasuista:

\section{Esimerkki 8. KPK 46:46}

$1 \quad$ Taisin itse kysyä, kuinka kauan puvut ovat miehillä olleet.

2 "Pari vuotta. Kansallispuvut on niin HANKALIA. " Sanoo

3 moneen otteeseen hankaluuden. "Ja eikä ne tämmösiin

4 'roskatilaisuuksiin" passaakaan. Mitä täällä olis

$5 \quad$ kansallispuvulla virkaa. Ei mitään. Virtain päivillä ja muissa

$6 \quad$ kunnon tilaisuuksissa on toinen asia. "Tosin nuokin livit perin

7 kuumat.

Kysyn ainoastaan, miten kauan ryhmä on käyttänyt esiintymisasuna sininen liivi - harmaat housut -yhdistelmää. Johtaja nähtävästi katsoo että kysymykseni sisältää implisiittistä ihmettelyä siitä, mikseivät he pidä kansallispukuja. Hän lisää heti vastauksensa perään huomion kansallispuvuista ja niiden 'hankaluudesta'. Kansallispuku on 1970-luvulta lähtien ollut pelimannin jäsenyyskategoriaan läheisesti liittyvä piirre. Etnometodologisesti Rajan kommentin voi tulkita siten, että kulttuurisen konvention paineesta hänen on kommentoitava normista poikkeavaa vaatetusta, tässä tapauksessa itsetodistelun (ks. Suoninen 1993, Juhila 1993) avulla - ainakin kansanmusiikin tutkijalle. Tässä on kiintoisaa, miten identiteetti aktualisoituu: puvustuksen suhteen kansallispukuinen pelimannius odottelee aivan nurkan takana, kansallispukurepertuaari voidaan ottaa käyttöön tarvittaessa.

Todistelussa kansallispuvut rakennetaan ensinnäkin epäkäytännöllisiksi ja toiseksi juhlavampiin tilaisuuksiin - ei roskatilaisuuksiin kuuluvaksi asuiksi (rivi 4). Kansallispuku sopii kunnon tilaisuuksiin kuten Virtain päiville. Virtain päiviin voidaan yhdistää Bogatyrevin mainitsemista funktioista ainakin pukeutumisen juhlafunktio ja alueellinen funktio. Ravintolassa vietettävässä pikkujoulussa kansallispuvulla 'ei olis mitään virkaa'. Tämä toisaalta liittyy myös 1978 perustetun kansallispukuneuvoston ja -raadin puvun käytölle asettamiin reunaehtoihin (ks. Jokinen, Juhila ja Suoninen 1993), joissa korostetaan, että puku on juhlapuku. Kansallispuvun ympärille on rakennettu ylevää ilmapiiriä jo pitkään. Erityisesti tutkijat ovat luoneet arvovallallaan kuvaa aidosta, tieteelliseen tutkimukseen perustuvasta pukuperinteestä. He ovat myös luoneet yhä tiukkenevan säännöstön puvulle, jota Vesa Kurkela (1989, 221-227) kutsuu hobsbawmilaisittain "perinnekeksinnöksi".Tässä kohtaa Virtain pelimannien 
johtaja käyttää näitä normeja perustellessaan pelimannien pukeutumattomuutta tai pukeutumista kansallispukuun.

Sileä trikoosamettikangas kelpaa juhlavaatteisiin, mutta siitä tehty liivi on myös käytännöllinen. Se on kuuma, mutta silti paljon kevyempi kuin kansallispuvun liivi. Useinhan juhlatilaisuuksissa parrasvaloissa irtoaa hiki. Pelimannit soittavat nykyisin mielellään tanssimusiikkikeikkoja. Tämä vaikuttaa paitsi ohjelmistoon myös pukeutumiseen. Näitä molempia on pitänyt sopeuttaa tilanteiden tarpeisiin.

Pohjoishämäläisten pelimannien Pelimannitalkoissa Vilppulassa vuonna 1989 kiinnitin huomiota siihen, että useat pelimanniryhmät käyttivät kansallispukua muistuttavia esiintymisasuja. Ystäväni huomautti jo juhlatalon pihalla "hienoista herroista puku päällä". Pelimannit olivat menossa juhliinsa "soitinkoteloineen, siistit vaatteet ja päällystakit yllä'". Naisista enemmistö oli yleisöä, eivätkä hekään tulleet paikalle arkikamppeissaan:

\section{Esimerkki 9. 150:195 KPK; Soittotalkoot Vilppulan urheilutalolla 4.3.89}

$1 \quad$ Markku oli todennut, että ympärillä on hienoja herroja puku päällä.

2 Todellakin, taloa kohti meni vanhahkoja pelimanneja

3 soitinkoteloineen, siistit vaatteet ja päällystakit yllä ja myös miehiä

4 puvut päällä.Naisetkin olivat tälläytyneet: (totesin sisällä) hameet,

$5 \quad$ kampaukset, korut. Katselin ulkopuolella vähän aikaa, näkisikö

6 pelimanneja (virtolaisia). Lasissa oli ilmoitus, kuva Pohjaslahden

7 pelimanneista puvuntakeissaan, joissa oli rintapielissä heidän oma

8 logonsa. (--)

Järjestävä ryhmä, Pohjaslahden pelimannit, oli pannut kuvansa oven lasiin: kuvassa heillä oli yllään logolla varustettu puvuntakki. Esiintyessään he käyttivät samanväristä, sinipunaiseen vivahtavaa liiviä, jossa oli rintapielessä samainen logo. Tämä asu kuulostaa melko monikäyttöiseltä. Puvuntakeissa ryhmä näyttää hyvinkin tyylikkäältä vanhaa tanssimusiikkia soittavalta orkesterilta. Soittotalkoiden tapaisissa tilanteissa, joissa he esittäytyvät "pelimanneina" muiden pelimannien joukossa, liiviasu on enemmän paikallaan.

Monien muidenkin Pelimannitalkoiden ryhmien asuihin kuului kankaasta tehty liivi, jossa oli ryhmän logo, kunnan vaakuna tai ryhmän nimellä varustettu laatta rintapielessä. Joku voisi nimittää näitä Pohjaslahden tai Keuruun tai Ruoveden pelimannien esiintymisasuja pseudokansallispuvuiksi, mutta itse en tätä sanaa käyttäisi. Toisaalta ne sijoittuvat kansallispuvun, tavallisen puvun ym. juhlavaatteiden välitilaan. Puvut ratkaisevat pelimanniryhmien pulman yhtenäisestä, näyttävästä vaatetuksesta aivan kansallispuvun tapaan. Puvun nimittäminen 'pseudokansallispuvuksi' asettaisi kansallispuvun ikään kuin geneeriseksi normiksi, josta pohjaslahtelaisten tai keuruulaisten puku on poikkeus. Allekirjoitan tässä pukeutumistutkija Minna Uotilan näkemyksen: 
"enemmän kaivataan tietoisuutta erilaisten kuvakäsitysten olemassaolosta - ja ennen kaikkea olemassaolon oikeudesta" (Uotila 1995, 171).

Myös Helena Ruhkalan haastattelemat virtolaiset musiikinharrastajat antavat erilaisille pukeutumistavoille oikeuden olla olemassa. Esimerkiksi nykykansanmusiikki ja nykyiset vaatteet sopivat haastateltavien mielestä hyvin yhteen. $(1989,79)$ Katja Riiholan haastattelussa puoli vuosikymmentä myöhemmin Virtain pelimannien johtaja mietti, että joskus kansallispukujen käytöllä saatetaan hämätäkin kuulijoita, sen avulla saatetaan saada jotain soiton puolelta anteeksi $(1995,117$.) Virtolaisten kaksirivisryhmien ohjaaja Airi Hautamäen mielestä kansallispuvut taas kuuluvat ehdottomasti kansanmusiikkiin (Riihola mt.). Hänestä on ihanaa kun tytöt - poikia kaksirivisryhmissä ei juuri ole - käyttävät esiintymisissään kansallispukuja. "Niinku Kaustisillekin mennään ni sehän sopii kesään ja se kansallispuku ni se on musta niin nätti ja siinä kaksirivinen" (Riihola mt.). Myös kaksirivisen soittajatytöt pitävät kansallispukuja kansanmusiikkiin kuuluvina: he seuraavatkin yleensä kaikessa johtajaansa Airia, joka on heille tärkeä samastumishahmo.

\section{Lopuksi}

Kaaviossa 1 esitän tiivistetyssä muodossa käyttämäni käsitteet. Ne ovat kaikki olleet omalla tavallaan relevantteja analyysissani. Barthesin käsitteistä le costume, puku, soveltuu suoraan pelimannien pukeutumiseen. Soittajien puvut ovat yhteisöllisiä ja rakentavat suhdetta puvun kantajan ja ryhmän välillä. Puku ja l'habillement vertautuvat suoraan vuorovaikutusstrategioihin, joita olen kutsunut kategorisoinniksi ja partikularisoinniksi. Ryhmän yhteisyyden ja kategoriapiirteiden rakentaminen on läsnä partikularisaatiota voimakkaammin. Tosin sama pukeutuminen palvelee joissakin yhteyksissä kategorisaatiota ja toisissa taas eriyttämistä. Paikallistasolla kansallispuku yhtenäistää, mutta alueellisella tasolla myös eriyttää. Samoin toimivat vaakunoilla tai nimilaatoilla varustetut erilaiset liivipelimannipuvutkin.

Olen käyttänyt hyväkseni Bogatyrevin jaotteluja pitkin matkaa.Virtolaiset käyttävät kansallispukua juhlapukuna kansallispukuneuvoston hengen mukaisesti - vaikkakin pieniä vapauksia ottaen. Trikoosamettiliivi - suorat housut -yhdistelmä taas sijoittuu juhla- ja arkipukujen välitilaan. Kaavioon 2 olen koonnut sekä aineistosta esiintulleita että omia tulkintojani Virtain pelimannien puvuista. Siinä käytän hyväkseni eritoten Bogatyrevia. 


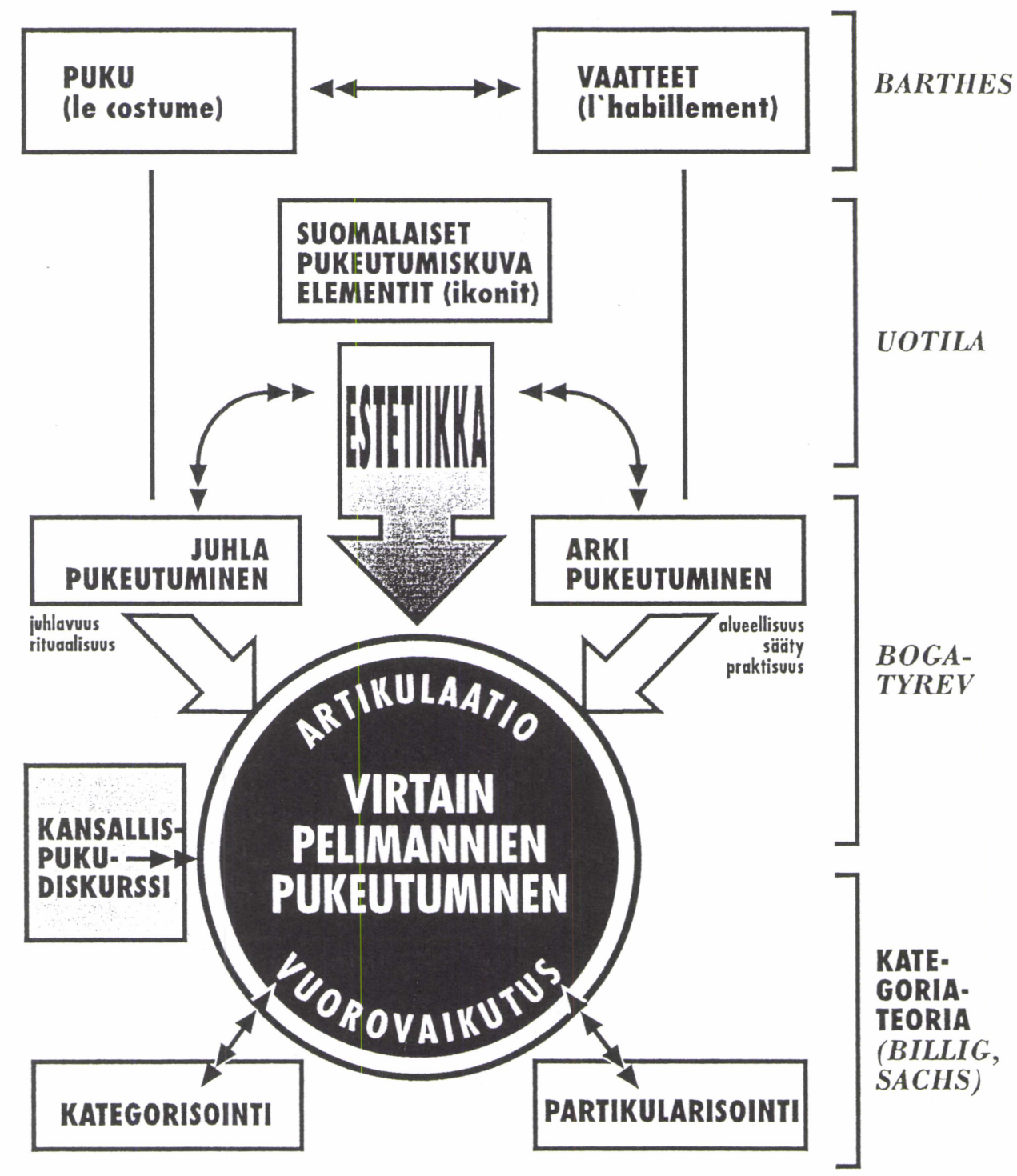

Kaavio 1. Tiivistelmä: pelimannien pukeutumiseen liittyvät käsitteet. 


\author{
VIRTAIN PUKU \\ Ylevän juhlava \\ Korostaa alueellisuutta $\mathrm{mm}$. \\ muinaisuuden merkein \\ Muoto yritetään sanella 'ylhäältä' \\ yksityiskohtia myöten \\ Levinnyt kaikkiin yhteiskunta- \\ kerrostumiin \\ Epäkäytännöllinen, \\ kallis \\ Merkki menneisyydestä \\ Entisajan materiaaleja ja teko- \\ tapoja jäljittelevä \\ Korostaa yhteyttä ryhmää \\ laajempaan kokonaisuuteen
}

HOUSU-LIIVI -YHDISTELMÄ

Asiallisen siisti

Sitoutuu paikkaan nykyhetken merkein (logo)

Ryhmä saa päättää yksityiskohdista, oma estetiikka määräävä

Keski- ja työväenluokkaisia piirteitä (vrt. vartija, bussinkuljettaja)

Käytännöllinen, edullinen

Tätä päivää

Nykyajan materiaalit ja tekotavat

Korostaa ryhmän yhteisyyttä

Kaavio 2. Virtain pelimannien pukeutuminen. Vrt. kaavio 1.

Pelimannien pukeutuminen on mielenkiintoinen ja monisäikeinen asia: tässä ehti vasta riisua hatun Laihon ja Leinon ilmaisua (1987) lainatakseni. Jatkossa olisi syytä pohtia vaikkapa nykykansanmusiikin pukeutumista ja sen suhdetta musiikkiin. Tutkimani pelimannit rakentavat pukeutumisella ryhmänsä yhteisyyttä: he koettavat vähentää sen sisäistä eriytymistä mahdollisimman pitkälti. Nykykansanmusiikissa sen sijaan sooloilu, yksilöllisyys, l'habillement, näkyy, paitsi soololevyjen yleistymisessä, myös pukeutumisessa. Kansallispukujahan esim. Sibelius-Akatemian kansanmusiikinopiskelijat eivät käytä. Jonkinlaisia myönnytyksiä nykykansanmusiikki-ihmisetkin tekevät sille, että he soittavat kansanmusiikkia. Se voi olla läsnä jonkinlaisina merkkeinä: valkoinen paita ja mustat liivit ovat yleisiä, musta hattu tai kansallispuvusta pelkkä vyö, käsityöläisten värjäämät kankaat. ${ }^{11}$ Värttinän vanavedessä monet muutkin yhtyeet pukeutuvat kukkamekkoihin, jotka ovat omalla tavallaan pikkuisen kapinallisen nostalgisia (vrt. '50-luvun kretongit'). Ainakin yksi asia yhdistää Virtain pelimanneja ja monia nykykansanmusiikkiyhtyeitä: liivi näyttää olevan tietynlainen kansanomaisuuden merkki.

Liivit ja valkeat paidat ovatkin tärkeä osa tukkilaiselokuvista tuttua suomalaisen pukeutumisen ikonimaisemaa. Uuskansanmuusikkojen kretonkimekot kuuluvat samoin suomalaisiin pukeutumiskuvaelementteihin. (vrt. Uotila

11 Viimeksi mainittu tosin tuntuu viittaavan yleisemminkin ammattikuntaan 'luovat sekatyöläiset'. 
1995,168 .) Virtain pelimannien pukeutumisessa ei kuitenkaan hyödynnetä perusjätkä- tai naishahmoa liivin ideaa enempää; kansallispukuista Elovenanaishahmoa kylläkin. Suora housu - trikoosamettiliivi -yhdistelmä kumpuaa tietysti omalla tavallaan suomalaisesta pukeutumisikonien kokoelmasta, mutta sen eri kerrostumasta: 'arkijuhlallisesta' ja huomaamattoman asiallisesta.

Olen Minna Uotilan kanssa samaa mieltä siinä, että pukeutuminen on toimintaa, "joka sillan tavoin yhdistää ihmisen juuri hänelle ominaisella tavalla ympäröivään todellisuuteen" $(1995,13)$. Pukeutumisen tutkimus on yksi keino lähestyä ihmisyyden olemusta, itseyttä ja omien ratkaisujen ymmärtämistä (mt. 171). Uotilasta poiketen uskon kuitenkin, että esteettinen kietoutuu lähtemättömästi moniin käytännön, moraalisiin ja taloudellisiin aspekteihin: niitä ei ole kovin helppo sulkeistaa tutkimuksen ulkopuolelle. Lääkärinkään ei kannata tappaa potilasta vain, jotta hän saisi paremman kuvan siitä, kuinka tämän verenkierto toimii (Eagleton 1991, 126). Kun tutkimani pelimannit pukeutuvat ja keskustelevat pukeutumisesta, he rakentavat siltaa ympäröivään todellisuuteen, joka on raadollinen ja monimuotoinen.

\section{Lähteet}

Kirjallisuus

Barthes, Roland 1957. Histoire et sociologie du vêtement. Quelques observations méthodologiques. - Annales, Economies Sociétés Civilisations. 12e Année No 3, s. 430-441. Paris.

Barthes, Roland 1967. Systéme de la Mode. Éditions du Seuil. Paris.

Billig, Michael 1987. Arguing and thinking. A rhetorical approach to social psychology. Cambridge University Press: Cambridge.

Bogatyrev, Petr G. 1971. The functions of folk costume in Moravian Slovakia. The Hague.

Eagleton, Terry 1991. Kirjallisuusteoria. Johdatus. Tampere: Vastapaino.

Elias, Norbert 1978. The Civilizing Process. The History of Manners. Oxford: Basil Blackwell.

Frith, Simon 1994), esitelmä Tukholmassa "What is bad music?", maaliskuu (painamaton).

Järviluoma, Helmi 1986. Musiikki, liikkeet, hillikkeet. Talonpoikaiston ja työväestön musiikinviljely kolmessa Ylivieskan kylässä vuosina 19001939. KPL 11.

Järviluoma, Helmi 1991. Johdanto. -Etnomusikologi ja kentän paikallinen tuottaminen. Lisensiaatintutkimus, Tampereen yliopiston kansanperinteen laitos, s. 2-29.

Järviluoma, Helmi 1994. Musiikin hyvät, pahat ja rumat. Tutkija Simon Frith kirjoittaa populaarimusiikin estetiikkaa. Aamulehti 10.4. 
Järviluoma, Helmi (tulossa). Local Construction of Gender in a rural pelimannimusicians group. - Music and Gender: Negotiating Shifting Worlds, ed. by Beverley Diamond and Pirkko Moisala. (Tulossa 1996.)

Järviluoma, Helmi ja Roivainen, Irene (painossa). Jäsenkategorisoinnin analyysi kulttuurisena metodina. Sosiologia 3/1996.

Jokinen, Arja, Juhila Kirsi ja Suoninen, Eero 1993. Diskursiivinen maailma: teoreettiset lähtökohdat ja analyyttiset käsitteet. -Diskurssianalyysin aakkoset, toim. Jokinen A., Juhila K. ja Suoninen E. Tampere: Vastapaino.

Juhila, Kirsi 1993. Miten tarinasta tulee tosi: Faktuaalistamistrategiat viranomaispuheessa. -Diskurssianalyysin aakkoset, toim. Jokinen A., Juhila K. ja Suoninen E. Tampere: Vastapaino.

Kolehmainen, Ilkka ja Saha, Hannu 1987. Onko Konsta Jylhä iskelmäsäveltäjä? -Kansanmusiikista populaarimusiikiksi, toim. Ilpo Saunio. Helsinki: Kansanmusiikin Keskusliitto.

Kurkela, Vesa 1989. Musiikkifolklorismi \& järjestökulttuuri. Kansanmusiikin ideologinen ja taiteellinen hyödyntäminen musiikki- ja nuorisojärjestöissä. Helsinki: Suomen etnomusikologisen seuran julkaisuja 3.

Laiho, Marianna ja Leino, Ritva 1987. Muodikkaan subjektin jäljillä. Tampereen yliopiston sosiologian ja sosiaalipsykologian laitos, pro gradu -tutkielma. (Painamaton.)

Laitinen Heikki 1977. 'Kaustislaisuuden synty.' Kaustisen ensimmäiset kansanmusiikkijuhlat ja maaseutukulttuurin paluu 1960-luvun Suomessa. Helsingin yliopiston folkloristiikan laitos, laudaturtyö. (Painamaton.)

Laitinen, Heikki 1989. Suomalaisen kansanmusiikkiliikkeen taustasta ja luonteesta. -Kansanmusiikki 2.

Lönnqvist, Bo 1972. Dräkt och mode i ett landsbygdsamhälle 1870-1920. (Dress and Fashion in a Rural Community.) Kansatieteellinen arkisto 24. Suomen muinaismuistoyhdistys, Helsinki.

Lönnqvist, Bo 1979. Kansanpuku ja kansallispuku. Helsinki: Otava.

Moerman, Michael 1975. Accomplishing Ethnicity. Teoksessa Roy Turner (ed.) Ethnomethodology. Harmondsworth: Penguin Education. (First published 1974.), ss. 54-68.

Riihola, Katja 1995. Virtain kansanmusiikkimaailma. Esimerkkeinä Virtain pelimannit ja Kurjenkylän kaksiriviset. -Musiikkimaailmoja ja äänimaisemia. Virtain kuulokulma. Toim. Helmi Järviluoma, KPL:n julkaisuja n:o 21, Virtain tutkimuksia 13, s. 111-122.

Ruhkala, Helena 1989. Virtolaisten musiikinharrastajien käsityksiä kansanmusiikista. - Soivat Virrat. Musiikkikulttuurin tapausanalyyseja, toim. Päivikki Suojanen. Tampereen yliopiston kansanperinteen laitoksen moniste 14, Tampere, s. 77-86.

Suoninen, Eero 1993. Kielen käytön vaihtelevuuden analysoiminen. -Diskurssianalyysin aakkoset, toim. Jokinen A., Juhila K. ja Suoninen E. Tampere: Vastapaino. 
Uotila, Minna 1995. Pukeutumisen kuvaus. Kuvia kulttuurin merkeistä. Helsinki: Yliopistopaino.

\section{Arkistolähteet}

KPL Y. Tampereen yliopiston kansanperinteen laitoksen yleiskokoelmat KPK. Kenttäpäiväkirjat vuosilta 1988-1994, kirjoittajan hallussa.

\section{Muut lähteet}

Terttu Vuorenpään haastattelu Virroilla syyskuussa 1995. Haastattelijana H. J. Litteraatio kirjoittajan hallussa.

Jaakko Ahon (Virrat) puhelinhaastattelu 1994. Haastattelijana H. J. 